\title{
EFEKTYWNY SYSTEM WYNAGRADZANIA W JEDNOSTKACH SAMORZĄDOWYCH OFERUJĄCYCH WSPARCIE FINANSOWE Z UNII EUROPEJSKIEJ JAKO KLUCZOWY INSTRUMENT WDRAŻANIA INNOWACYJNYCH METOD ZARZĄDZANIA W ORGANIZACJACH PUBLICZNYCH
}

\begin{abstract}
Streszczenie
Autorzy w artykule dokonują analizy obszarów podatnych na implementację innowacji w instytucji publicznej, oferujacej wsparcie finansowe ze środków Unii Europejskiej. Wskazują system wynagradzania jako możliwe pole działania do wdrożenia ewentualnych zmian. Swoje rozważania popierają wynikami pilotażowego badania zrealizowanego w 2011 roku wśród 79 pracowników Centrum Obsługi Przedsiębiorcy w Lodzi w zakresie oceny efektywności systemu wynagradzania i jego wpływu na poziom satysfakcji i motywacji pracowników. Celem artykułu jest ocena roli, jaką system wynagradzania odgrywa w analizowanej instytucji publicznej, odpowiedzialnej za wdrażanie jednego z priorytetów Regionalnego Programu Operacyjnego Województwa Lódzkiego na lata 2007-2013.
\end{abstract}

Słowa kluczowe: sektor publiczny, innowacyjność, zarządzanie zasobami ludzkimi, system wynagradzania, zarządzanie przez cele, Unia Europejska

\section{EFFECTIVE WAGE SYSTEMS IN LOCAL GOVERNMENT UNITS OFFERING FINANCIAL SUPPORT FROM EUROPEAN UNION AS KEY INSTRUMENT OF IMPLEMENTATION OF INNOVATIVE MANAGEMENT METHODS IN PUBLIC ORGANISATIONS}

\section{Summary}

The authors examine the areas open to the implementation of innovation in public institutions offering financial support from the European Union funds. It seems that wage systems are a promising field for the implementation of changes. The analysis is based on the results of a pilot survey, conducted in 2011 among 79 employees of the Entrepreneur Service Centre in Lódź, regarding the assessment of the effectiveness of the wage system and its influence on the level of satisfaction and motivation of employees. The aim of the paper is to assess the role that the wage system plays in the analysed public institution responsible for the implementation of one of the priorities of the Regional Operational Programme for Lódzkie Voivodeship for the years 2007-2013.

Key words: public sector, innovation, human resources management, wage system, management by objectives, European Union

${ }^{1}$ dr Janusz Kornecki - Wydział Zarządzania Uniwersytetu Lódzkiego; e-mail: kornecki@uni.lodz.pl; mgr Maciej Kokotek - Wydział Zarządzania Uniwersytetu Lódzkiego (doktorant); e-mail: kokomak@yahoo.com; mgr Arkadiusz Szymański - Wydział Zarządzania Uniwersytetu Lódzkiego (doktorant); e-mail: arkady4@vp.pl. 


\section{Wstęp}

W latach 2007-2013 Polska stała się największym beneficjentem środków pomocowych UE spośród wszystkich „nowych” państw członkowskich Unii Europejskiej. Całkowita kwota środków przeznaczonych na realizację projektów sektorów: publicznego, prywatnego i pozarządowego, wraz ze współfinansowaniem krajowym i inwestycjami kapitału prywatnego, wyniosła łącznie ponad 100 mld euro. W porównaniu z poprzednim okresem programowania Unii Europejskiej, zmieniła się systematyka programów pomocowych i zasady ich wdrażania [Cieślak, 2008, s. 15]. Znaczną część wsparcia przewidziano do implementacji poprzez 16 Regionalnych Programów Operacyjnych, oddając samorządom wojewódzkim całkowitą decyzyjność w zarządzaniu nimi. W efekcie wymagało to: zbudowania nowego systemu instytucjonalnego, przejęcia nowych zadań i przygotowania wykwalifikowanej kadry urzędniczej.

Uzmysłowiono sobie potrzebę wprowadzenia zmian w sposobach zarządzania zasobami ludzkimi. Wyzwanie, przed jakim stanęły instytucje publiczne oferujące wsparcie finansowe z Unii Europejskiej, skłoniło osoby odpowiedzialne za kreowanie polityki regionalnej na poziomie województw do poszukiwania nowych rozwiązań, niezbędnych do implementacji zmian instytucjonalnych i kadrowych. Szczególnie ważne dla udanego wprowadzenia zmian w systemie działania instytucji publicznych, warunkujące efektywną alokację powierzonych środków finansowych, stało się wprowadzenie w ich funkcjonowaniu innowacji organizacyjnych.

Takie podejście było jak najbardziej zgodne z jednym z celów zawartych w Narodowych Strategicznych Ramach Odniesienia na lata 2007-2013 (NSRO), najważniejszym krajowym dokumencie określającym kierunki wsparcia ze środków finansowych, dostępnych z budżetu UE w ciagu kolejnych siedmiu lat w ramach: Europejskiego Funduszu Rozwoju Regionalnego, Europejskiego Funduszu Społecznego oraz Funduszu Spójności. To właśnie w pierwszym celu horyzontalnym NSRO zdefiniowano Poprawe jakości funkcjonowania instytuci publicznych oraz rozbudowe mechanizmów partnerstwa, co wpisywało się również w wytyczną 1.3.4 Strategicznych Wytycznych Wspólnoty - Zdolności administracyjne [Narodowe Strategiczne Ramy Odniesienia..., 2006, s. 53].

Spośród wielu różnorodnych aspektów funkcjonowania organizacji publicznej, w których może się przejawiać innowacyjność procesu zarządzania, rozważania podjęte w niniejszym artykule koncentrują się na jednym z podstawowych i najważniejszych instrumentów zarządzania, jakim jest system wynagradzania.

Celem artykułu jest ocena roli, jaką system wynagradzania odgrywa w instytucji publicznej - Centrum Obsługi Przedsiębiorcy w Lodzi (COP), odpowiedzialnej za wdrażanie jednego z priorytetów Regionalnego Programu Operacyjnego Województwa Lódzkiego na lata 2007-2013. Artykuł został przygotowany na podstawie: literatury przedmiotu, wywiadów z kierownikami samorządowej jednostki organizacyjnej, obserwacji oraz własnych doświadczeń autorów. W opracowaniu zaprezentowano również wyniki pilotażowego badania, któremu we wrześniu 2011 roku poddano 79 pracowników COP. Narzędziem wykorzystanym w badaniu był kwestionariusz ankiety. 


\section{Zachowania innowacyjne w zarządzaniu organizacjami publicznymi}

Pojęcie innowacyjności, które zostało wprowadzone do ekonomii przez Schumpetera już na początku XX wieku, cieszy się stale niesłabnącym zainteresowaniem zarówno w świecie nauki, jak i pośród praktyków. Przy niejednoznaczności tego terminu oraz braku powszechnie przyjętej definicji, dopiero czasy współczesne nadały tej kategorii sens, uznając ją za motor postępu społeczeństwa [Styś, 2011, s. 16]. Co więcej, wśród autorów opracowań naukowych i konsultantów w dziedzinie zarządzania panuje akceptacja poglądów, że innowacje stanowia podstawę rozwoju organizacji XXI wieku [Czapla, Świątek-Barylska, 2011, s. 80]. Innowacja może oznaczać nowe sposoby myślenia i gotowość spojrzenia na otaczająca nas rzeczywistość w zupełnie odmienny sposób.

Wielu autorów z dziedziny zarządzania określa innowacje jako przekształcenie nowego pomysłu w: nową firmę, nowy wyrób, nową usługę, nowy proces albo nową metodę produkcji [Stoner i in., 2001, s. 412]. Powszechnie używa się tego terminu także w odniesieniu do nowatorskich działań podejmowanych przez przedsiębiorstwa w celu podniesienia swojej konkurencyjności i zapewnienia stabilizacji na stale rozwijającym się rynku. Jednakże niewiele uwagi poświęca się określeniu znaczenia i charakteru innowacji $\mathrm{w}$ instytucjach publicznych. Ponadto, istnieje przekonanie, że innowacje w zarządzaniu organizacjami publicznymi odgrywają marginalną rolę, co nie sprzyja wprowadzaniu zmian i procesów rozwojowych [Wiatrak, 2011, s. 11].

Natomiast innowacje w dzisiejszych czasach stały się jednym z kluczowych czynników decydujących o sukcesie organizacji, tym samym w ocenie autorów powinny one znaleźć swe zastosowanie nie tylko w przedsiębiorstwach, ale również w organizacjach publicznych. W każdej organizacji, także o charakterze publicznym, wskazane i oczekiwane jest posiadanie umiejętności dostosowania się do zachodzących zmian. Proces ten powinien być przeprowadzony szybko, w sposób efektywny i racjonalny. Zarządzanie w nowoczesnej administracji wychodzi obecnie daleko poza bierne reagowanie i adaptację. Zakłada odpowiedzialność za: dążenie do kształtowania środowiska instytucjonalnego, kultury organizacyjnej, planowanie, inicjowanie i przeprowadzanie zmian. To jednocześnie odpowiedzialność za stałe rozszerzanie granic, które swobodzie instytucji publicznej narzucają liczne bariery. Wśród ograniczeń, które mogą hamować implementacje innowacji w instytucjach publicznych, oprócz uwarunkowań formalno-prawnych, należy wymienić m.in.: kulturę organizacji publicznej; dużą liczbę stosowanych procedur; przekonanie pracowników, że są zapracowani i słabo opłacani; dominację interesariuszy politycznych oraz burzliwe otoczenie polityczne [Krukowski, 2011, s. 28].

Innym aspektem zarządzania instytucjami publicznymi jest wypełnianie funkcji publicznych, co sprowadza się do realizacji ustawowo nałożonych zadań w ogólnie pojętym interesie społecznym, zgodnie $z$ wszelkimi normami prawa. Wypełnianie funkcji publicznych służy równocześnie wprowadzaniu innowacji, jako że innowacje pozwalaja poprawić jakość świadczonych usług i zwiększyć zaangażowanie pracowników w wykonywaną pracę. W tym celu działania innowacyjne powinny być oparte na kompleksowej organizacji pracy, łączącej wszystkie zachodzące w niej procesy oraz wszystkich uczestników i pracowników, bowiem każda produktywna czy efektywna organizacja istnieje dzięki skutecznie działającym ludziom [Drucker, 1994, s. 44]. Przedsiębiorstwo to spo- 
łeczność istot ludzkich i jego wydajność to ich wydajność. Tymczasem społeczność istot ludzkich musi opierać się na wspólnych przekonaniach, zaś jej zwartość muszą symbolizować wspólne zasady. Inaczej dotknie ją paraliż, straci ona zdolność działania, nie będzie mogła domagać się ani uzyskiwać od swych członków wysiłku i wydajności [Drucker, 1994, s. 80]. Taki sposób zarządzania można nawet nazwać filozofia zarządzania. Powołuje się ona na swoistą koncepcję ludzkiego działania, ludzkich zachowań i motywacji.

Motywacja w tym ujęciu to również psychologiczny stan przyczyniający się do stopnia, w jakim człowiek angażuje się w coś. Obejmuje ona czynniki, które powoduja, wytyczają i podtrzymują zachowania ludzkie zmierzające w określonym kierunku. Innymi słowy, jest to proces kierowniczy, polegający na wpływaniu na zachowania ludzkie z uwzględnieniem wiedzy o tym, co powoduje takie, a nie inne postępowanie człowieka [Stoner $\mathrm{i}$ in., 2001, s. 426].

Niezwykle istotne staje się więc budowanie systemów motywacyjnych, na co składaja się działania służące opracowaniu efektywnych systemów zachęt materialnych i niematerialnych, motywujących pracowników do działania ukierowanego w stronę celów firmy. Działania te zawieraja: zbieranie informacji na temat rynkowej wysokości płac dla poszczególnych stanowisk pracy; tworzenie i wdrażanie motywacyjnych systemów wynagradzania, w tym procedur i narzędzi kształtowania zmiennych składników płacy; przygotowywanie projektów regulacji zakładowego prawa pracy w zakresie wynagrodzeń i świadczeń związanych z pracą oraz tworzenie, wprowadzanie i realizowanie systemu oceny wyników pracy i potencjału rozwojowego pracowników [Czapla, Malarski, 2001, s. 2].

Najszerszym polem do zastosowania innowacyjnych rozwiązań w organizacjach publicznych staje się proces zarządzania, obejmujący nowe techniki i metody w przyjętych zasadach działania, organizacji miejsca pracy bądź w stosunkach z otoczeniem, które pozwalają instytucji lepiej funkcjonować oraz realizować przyjęte cele i zadania. Dobór stosownych metod zarządzania zależy od: zarządzających instytucją publiczną, zakresu jej działania czy też problemu do rozwiązania. W ostatnich latach do najpopularniejszych metod należa: zarządzanie przez procesy, zarządzanie poprzez jakość, zarządzanie poprzez projekty i zarządzanie poprzez budżetowanie [Wiatrak, 2011, s. 21]. Do, wyżej wymienionych, sposobów zarządzania autorzy zaliczają również zarządzanie przez cele. W dalszej części pracy odnoszą się do kluczowej roli, jaką - w ich ocenie - ta metoda może odgrywać w innowacyjnym zarządzaniu instytucjami publicznymi.

\section{Możliwości stymulowania zachowań innowacyjnych w instytucjach publicznych}

Spośród licznie prezentowanych w literaturze determinant innowacyjności [por. np.: Penc, 2010, Stawasz, 1999] warto skupić się na tych, które mogą stymulować (lub blokować) pojawianie się innowacji w działalności instytucji publicznych. Mają one najczęściej swoje źródło w kulturze organizacji, a ta jest specyficzna dla każdego typu organizacji. Normy, wartości i zachowania są w nich często głęboko zakorzenione i tworzą 
rzetelną podstawę funkcjonowania organizacji wewnętrznej [Roodenburg-Jager i in., 1993, s. 218]. Właściwe nakreślenie pracownikom przestrzeganych wartości, wskazanie obowiązujących norm i wzorców postępowania, a także jasne przedstawienie sposobów realizacji nałożonych celów może być kluczowe, jeżeli chodzi o stworzenie stabilnego środowiska wewnętrznego, podatnego na wdrożenie innowacji.

Według Gadomskiej-Lili, kultura organizacyjna oraz struktura organizacji są najczęściej wymienianymi determinantami innowacyjności. Dynamiczna struktura organizacyjna, w której likwiduje się bariery między komórkami i to zarówno w pionie, jak i poziomie struktury, decentralizacja decyzji, większa partycypacja pracowników oraz niski stopień sformalizowania sprzyjają implementacji innowacyjności [Gadomska-Lila, 2011, s. 127]. Autorka wskazuje również istotną rolę pracy zespołowej jako formy współpracy sprzyjającej wymianie poglądów, uczeniu się i wyzwalającej efekt organizacyjny działania zbiorowego. Ponadto, do innych uwarunkowań wprowadzania innowacji w instytucjach publicznych można zaliczyć: ograniczanie biurokracji, delegowanie zadań i kompetencji, pobudzanie inwencji i przedsiębiorczości pracowników poprzez tworzenie właściwych systemów motywacyjnych oraz włączanie pracowników w proces zmian [Penc, 2001, s. 76].

Wymienione uwarunkowania innowacyjności w instytucjach publicznych są ze sobą ściśle powiązane. Określają w miarę kompletny katalog zachodzących w nich procesów i przekładaja się na podejmowanie lub zaniechanie działań innowacyjnych w instytucjach publicznych. W ocenie autorów niniejszego artykułu, właśnie ten obszar jest niezwykle istotny pod kątem możliwości zastosowania innowacyjnych metod zarządzania, zwłaszcza metody zarządzania przez cele. Można bowiem dojść do wniosku, że tym, czego danej instytucji publicznej potrzeba, jest taka metoda zarządzania, która umożliwi pełny rozwój indywidualnych sił ludzkich i odpowiedzialności, a równocześnie nada wspólny kierunek podejmowanym wysiłkom, zapewni zespołowość pracy, harmonizując $z$ dobrem wspólnym cele indywidualne. Według Druckera, można to osiągnąć dzięki zastosowaniu metody zarządzania przez cele, gdyż czyni ona wspólne dobro celem każdego kierownika. Zastępuje kontrolę $z$ zewnątrz surowszą, bardziej wymagająca, ale także skuteczniejszą kontrola własną [Drucker, 1994, s. 154].

W większości skutecznych systemów zarządzania przez cele występuje sześć elementów [Stoner i in., 2001, s. 295]: zaangażowanie, ustalanie celów na najwyższym szczeblu zarządzania, ustalanie celów indywidualnych, uczestnictwo, samodzielność w wykonywaniu planów oraz przeglądy efektywności.

Zarządzanie przez cele wykracza poza wyznaczanie rocznych zadań do wykonania przez poszczególne komórki organizacyjne. Daje ono możliwość wyzwolenia inicjatywy u pracowników za sprawa przyznania im pewnej dozy samodzielności, co może prowadzić do pojawienia się innowacyjnych zachowań i postaw wśród pracowników. Szczebel kierowniczy wraz z podwładnymi wspólnie opracowuja cele do osiagnięcia, ustalają niezbędne narzędzia do ich osiagnięcia czy wyznaczają terminy dokonywania pomiaru efektywności podjętych działań. Współuczestnictwo wszystkich pracowników staje się zasadnicze, gdyż wzrasta poczucie odpowiedzialności. 


\section{System wynagradzania funkcjonujący w Centrum Obsługi Przedsiębiorcy w Lodzi}

Powszechnie uznaje się, że wynagrodzenia sa głównym narzędziem motywowania ludzi do pracy, mimo że ich rola nie jest jednakowa we wszystkich grupach społecznozawodowych. Poprawnie skonstruowana i umiejętnie realizowana polityka płacowa może wydatnie przyczynić się do wzrostu efektywności i dynamicznego rozwoju każdej instytucji. Motywowanie płacowe wzmacnia bowiem poziom utożsamiania się pracowników z instytucja, wyzwala inicjatywę, skłania do poprawy wyników pracy, tworzy grunt dla efektywnego wykorzystania ograniczonych środków na wynagrodzenia, które szczególnie często podlegają limitowaniu w organizacjach publicznych.

Centrum Obsługi Przedsiębiorcy w Lodzi jest wojewódzką, samorządową jednostka organizacyjna, powołaną przez Sejmik Województwa Lódzkiego, działającą od 1 marca 2008 roku. Celem działania Centrum Obsługi Przedsiębiorcy, jako Instytucji Pośredniczacej II stopnia [Ustawa..., 2009, art. 27], jest pomoc potencjalnym beneficjentom w efektywnym wykorzystaniu środków finansowych, pochodzących z Europejskiego Funduszu Rozwoju Regionalnego. Centrum realizuje zadania w ramach III Osi priorytetowej: Gospodarka, innowacyjność, przedsiębiorczość Regionalnego Programu Operacyjnego Województwa Lódzkiego na lata 2007-2013.

$\mathrm{Na}$ początek warto scharakteryzować pokrótce system wynagradzania w Centrum Obsługi Przedsiębiorcy. W czasie przeprowadzania badania system wynagradzania w analizowanej instytucji został określony w Regulaminie Wynagradzania pracowników Centrum Obstugi Przedsiebiorcy, przyjętym na podstawie Zarządzenia Nr 1/10 Dyrektora Centrum z dnia 5 stycznia 2010 roku, opartym na Rosporzadzeniu Rady Ministrón z dnia 18 marca 2009 roku w sprawie wynagradzania pracowników samorzadonych [Regulamin mynagradzania, 2010].

Zgodnie z Regulaminem, pracownicy otrzymuja wynagrodzenie zasadnicze według Tabeli Kategorii zaszeregowań $i$ miesiecznych stawek uynagrodzen zasadniczych pracownikón Centrum Obstugi Præeedsiębiorcy. Oprócz płacy zasadniczej, pracownikowi Centrum Obsługi Przedsiębiorcy przysługuje:

- dodatek za wieloletnią pracę - uzależniony od liczby przepracowanych lat, należny po 5 latach pracy w wysokości 5\% miesięcznego wynagrodzenia zasadniczego i wzrasta o $1 \%$ za każdy następny rok pracy aż do osiagnięcia 20 -procentowego miesięcznego wynagrodzenia zasadniczego;

- dodatek funkcyjny - dla pracowników zatrudnionych na stanowiskach związanych z kierowaniem zespołem, a także na stanowisku głównego specjalisty;

- dodatek specjalny - dla pracowników z tytułu zwiększenia zakresu obowiazzków służbowych lub powierzenia dodatkowych zadań albo ze względu na charakter pracy lub warunki jej wykonywania.

W Regulaminie przewidziano: nagrodę jubileuszowa po przepracowaniu co najmniej 20 lat (wlicza się do niej wszystkie poprzednio zakończone okresy zatrudnienia), jednorazową odprawę w związku z przejściem na emeryturę lub rentę z tytułu niezdolności do pracy oraz dodatkowe wynagrodzenie roczne, określone w Ustanie z. dnia 12 grudnia 1997 r. o dodatkonym mynagrodzeniu rocznym pracownikón jednostek sfery budžetowej [Ustawa..., 1997]. 
Ponadto, w ramach posiadanych środków na wynagrodzenia, decyzją Dyrektora Centrum, pracownikom Centrum Obsługi Przedsiębiorcy mogą być przyznawane nagrody za szczególne osiagnięcia w pracy oraz premie uznaniowe, w szczególności przyznawane za: osiagnięcie w pracy dobrych wyników, wykonanie określonego zadania, terminowość, staranność i jakość wykonywania powierzonych czynności.

W opisanym w ten sposób systemie wynagrodzeń wyraźnie można wyodrębnić dwie części. Pierwszą, regulowaną reżimem prawnym, narzuconym Ustawa z dnia 26 czernwca 1974 roku Kodeks pracy [Ustawa..., 1974], Ustawa z. dnia 21 listopada 2008 roku o pracownikach samorzadowych [Ustawa..., 2008] oraz Rozporzadzeniem Rady Ministrów z dnia 18 marca 2009 roku w sprawie mynagradzania praconnikón samorzqadonych [Rozporz̨qdzenie..., 2009]. W jej zakres wchodzi płaca zasadnicza oraz pozostałe dodatki i uprawnienia płacowe, które zaszeregowane w stosownych widełkach, ujętych w formach tabelarycznych, pozostaja poza sferą uznaniowości Dyrektora Centrum.

Drugą częścią, którą można określić jako obszar swobody, stają się w tym podziale nagrody i premie uznaniowe, przyznawane przez Dyrektora Centrum, m.in. za szczególne osiagnięcia w wykonywaniu powierzonych obowiązków. Ten obszar może być w miarę swobodnie kreowany zarówno w zakresie ogólnie sformułowanych w Regulaminie kryteriów przyznawania, jak i terminu, a także częstotliwości ich przyznawania.

\section{Wyniki badań}

Celem badania, przeprowadzonego we wrześniu 2011 roku wśród wszystkich 79 pracowników Centrum Obsługi Przedsiębiorcy, była analiza potrzeb wprowadzenia zmian w obecnie funkcjonującym systemie wynagradzania oraz poziomu satysfakcji i czynników motywujących pracowników do efektywniejszej pracy. W badaniu wykorzystano, anonimowo wypełniany przez pracowników, kwestionariusz ankietowy (metoda PAPI - Paper and Pencil Interview) zawierajacy 24 pytania. Pytania dotyczyly m.in.: oceny możliwości, jakie praca stwarza do stymulowania rozwoju kwalifikacji; warunków awansu zawodowego oraz oczekiwanych w tym zakresie kryteriów; czynników podnoszacych i obniżających poziom motywacji wśród pracowników czy choćby jasności kryteriów systemu nagradzania.

Analiza odpowiedzi respondentów na pytanie o poczucie docenienia ich pracy ukazała satysfakcję większości pracowników w tym zakresie, co potwierdziło blisko $2 / 3$ respondentów (rysunek 1.). Jednakże ten, dość pozytywny, obraz był zakłócany przez negatywne wskazania co piątego pytanego, gdzie wśród przyczyn wymieniali oni np.: krytykę i zastrzeżenia zgłaszane przez przełożonych, mimo rzetelnie wykonanej pracy czy też brak motywowania pozytywnego pracowników. Brak jednoznacznej oceny (odpowiedzi „trudno powiedzieć”) wynikał z braku słów uznania ze strony przełożonych, nawet w sytuacji wykonania odpowiedzialnego i trudnego zadania. 
RYSUNEK 1.

\section{Opinie respondentów na temat doceniania ich pracy}

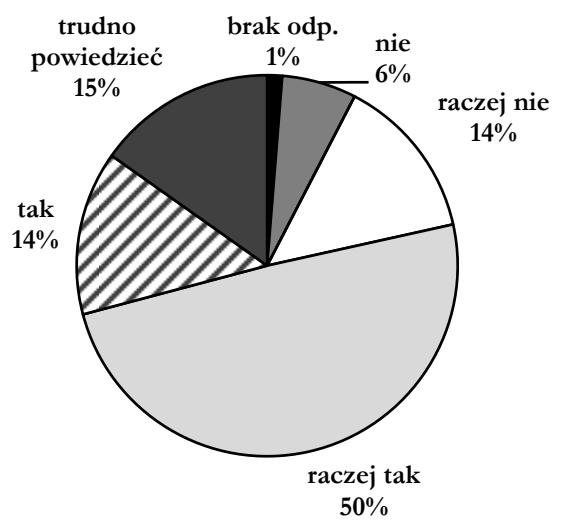

Źródło: badanie PAPI [n=79].

W ocenie zdecydowanej większości respondentów (89\%) wykonywana przez nich praca ma stymulujące oddziaływanie na rozwój ich kwalifikacji, a jedynie $10 \%$ ankietowanych nie dostrzegało takiego zwiazku (rysunek. 2.). Uzyskane wyniki ukazały na korzystne, pozafinansowe czynniki kształtujące środowisko pracy co, w połączeniu z satysfakcją w aspekcie materialnym, może zapewniać stabilność zespołu pracowniczego.

RYSUNEK 2. Opinie respondentów na temat stymulującego oddziaływania wykonywanej pracy na rozwój ich kwalifikacji

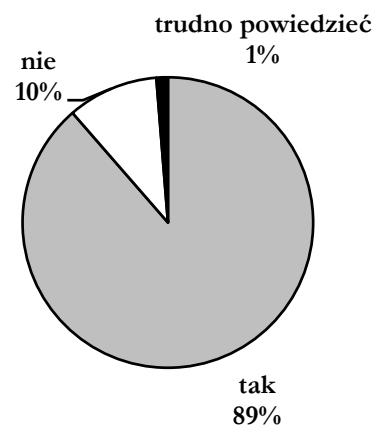

Źródło: badanie PAPI [n=79].

Respondenci mieli możliwość oceny, stosowanych w Centrum Obsługi Przedsiębiorcy, kryteriów awansu pod kątem ich postrzeganej sprawiedliwości (rysunek 3.). Za najbardziej sprawiedliwe kryteria awansowania pracowników uznano bardzo dobrą ocenę 
dotychczasowej pracy $(29 \%)$ oraz posiadanie predyspozycji i kompetencji na awansowane stanowiska $(26 \%)$. Natomiast najmniej sprawiedliwe kryteria to - w opinii respondentów - ukończenie szkół i uczelni (37\%) oraz wzrost zakresu obowiązków (15\%). Ocena tego drugiego czynnika najbardziej podzieliła respondentów, bowiem wzrost zakresu obowiązków został uznany za najbardziej sprawiedliwe kryterium awansowania przez $12 \%$ ankietowanych.

RYSUNEK 3.

\section{Kryteria awansowania pracowników uznawane na najbardziej i najmniej sprawiedliwe w opinii respondentów (respondenci wskazywali po jednym czynniku najbardziej i najmniej sprawiedliwym)}

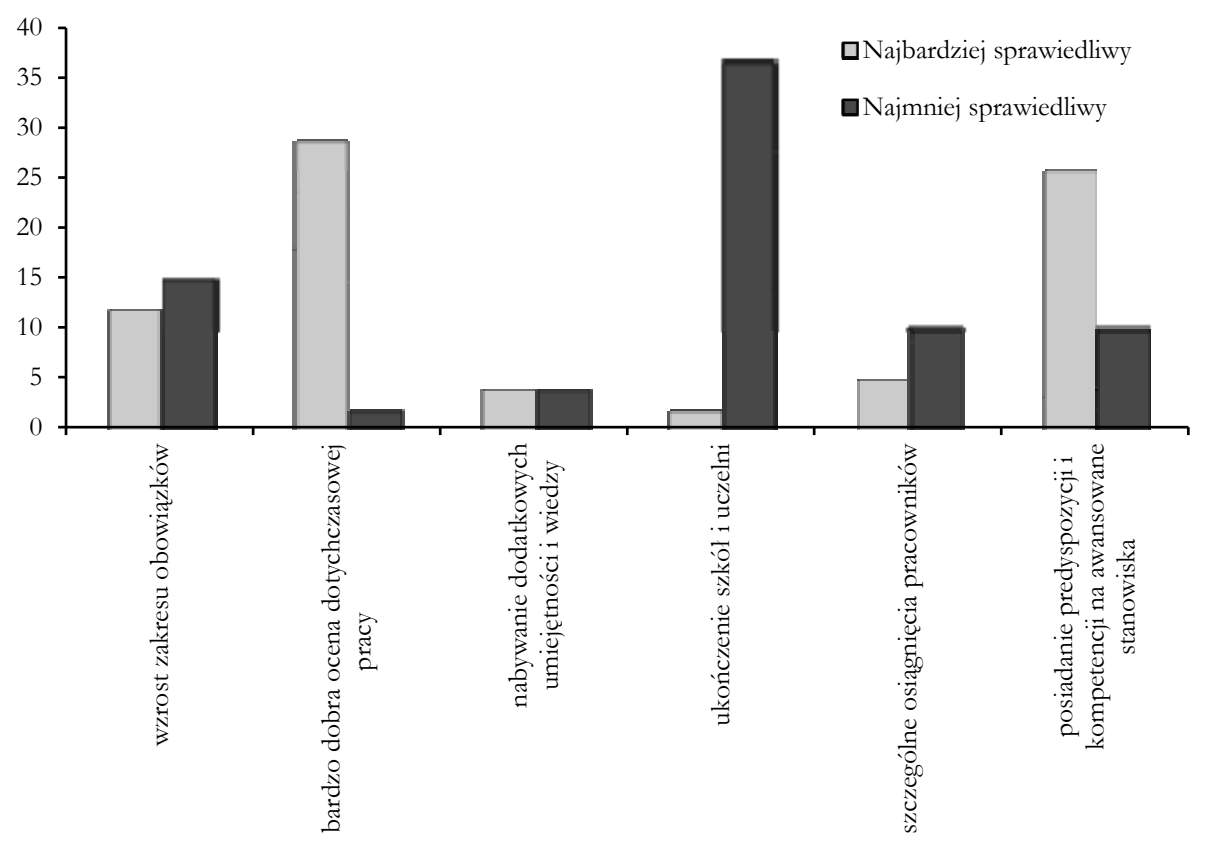

Źródło: badanie PAPI [n=79].

Analiza czynników zadowolenia z wykonywanej pracy ukazała, że w największym stopniu wpływają na nie: wysokość wynagrodzenia, możliwość rozwoju i awansu oraz dobre relacje z przełożonymi (rysunek 4.). Jedna osoba wymieniła dodatkowy element, oddziałujący na zadowolenie z pracy, a mianowicie wiarę w pozytywny wpływ wykonywanej pracy na społeczność lokalna. W przypadku mniej niż połowy respondentów zadowolenie z wykonywanej pracy kształtują: możliwość samodzielnego podejmowania decyzji, stabilność zatrudnienia i obiektywizm przełożonego. Warto także wskazać na miejsce pośrodku hierarchii czynników przyznane możliwości otrzymania nagrody bądź premii. Oznacza to, że pracownicy preferowali mniej uznaniowe formy finansowej gratyfikacji za wykonywana pracę. 
RYSUNEK 4.

Czynniki zadowolenia z wykonywanej pracy w opinii respondentów (możliwość wielu wskazan)

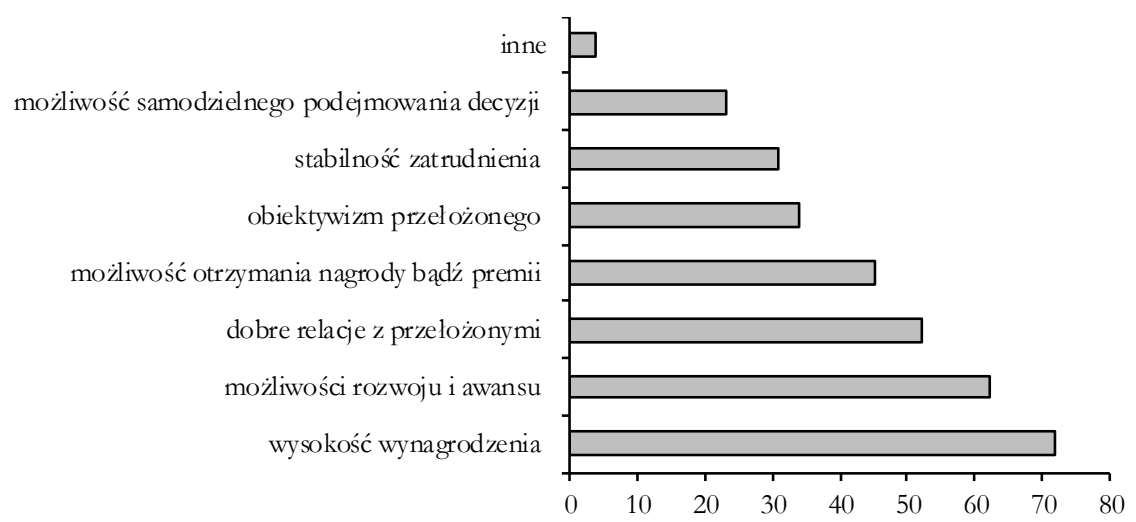

Źródło: badanie PAPI [n=79].

W dość zgodnej opinii respondentów najważniejszym czynnikiem, który powinien decydować o wzroście wynagrodzenia pracownika, jest dobra ocena kompetencji i efektów pracy, na co wskazały aż 72 osoby ( rysunek 5.). Ważne, zdaniem większości ankietowanych, czynniki uzasadniające wzrost wynagrodzenia to ponadto awans stanowiskowy (wskazany przez 55 osób) oraz poszerzenie zakresu obowiązków (49 osób).

RYSUNEK 5.

\section{Czynniki, które w opinii respondentów powinny decydować o wzroście} wynagrodzenia

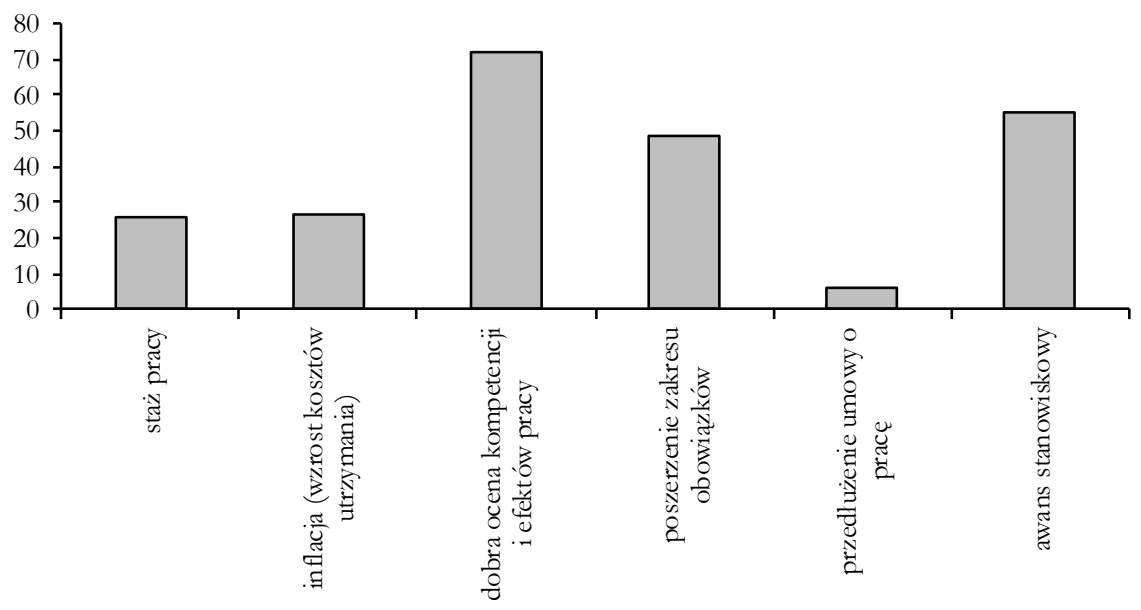

Źródło: badanie PAPI [n=79]. 
Respondenci wskazali, iż ocena bieżąca po wykonaniu zadania, czynności lub polecenia nie jest dokonywana (55 osób), choć w opinii większości ankietowanych jest potrzebna (48 osób). Uzyskane wyniki pokazują, że pracownicy chcieliby mieć informacje zwrotne od przełożonych, co pozwalałoby im kontynuować dalsze działania w przekonaniu, że dobrze je wykonują lub - w razie konieczności - podjąć działania korygujące.

RYSUNEK 6.

Potrzeba i skala stosowania bieżącej oceny pracy pracownika w opinii respondentów

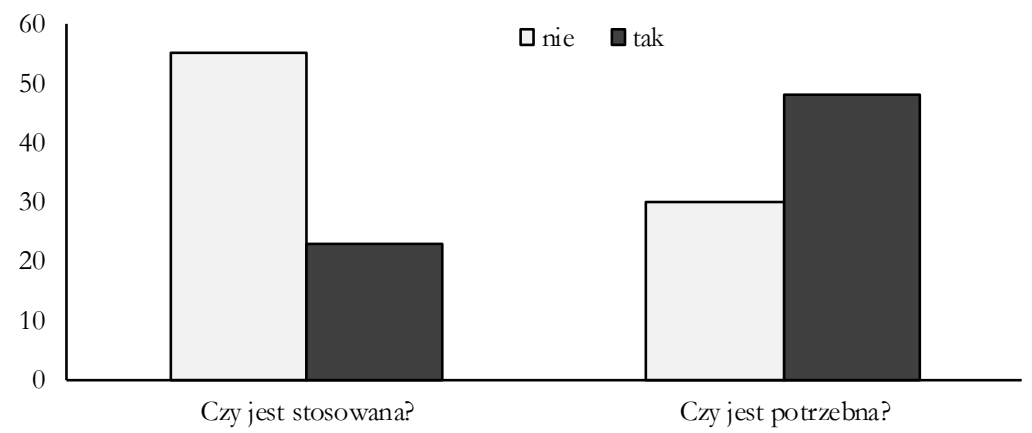

Źródło: badanie PAPI [n=79].

Badani wskazali również, że zasadniczo nie jest stosowana (68 wskazań) rozmowa uzasadniająca kwestie indywidualnego premiowania, mimo że w ocenie przeważającej większości respondentów jest ona potrzebna (58 wskazań). Niska skala stosowania takich rozmów wydaje się tłumaczyć względnie niską wagę stosowania systemu premiowego jako czynnika zadowolenia $\mathrm{z}$ wykonywanej pracy.

RYSUNEK 7.

Potrzeba i skala stosowania rozmów z pracownikami uzasadniającymi kwestie indywidualnego premiowania w opinii respondentów

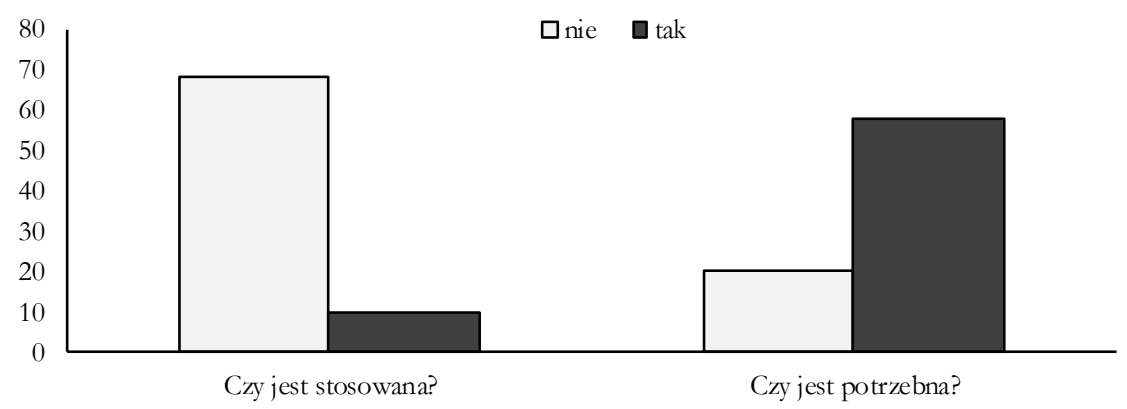

Źródło: badanie PAPI [n=79]. 


\section{Podsumowanie}

Informacje, zebrane w wyniku przeprowadzonego badania pilotażowego, prowadzą dość jednoznacznie do wniosku, iż w omawianej instytucji publicznej niezwykle korzystne byłoby zaimplementowanie innowacyjnej metody zarządzania, jaką jest zarządzanie przez cele. Zdecydowana większość ankietowanych przyznała, że praca w Centrum Obsługi Przedsiębiorcy pozwala na rozwój kwalifikacji pracowniczych. Jednocześnie ponad $1 / 3$ badanych nie czuła się doceniona w swoim miejscu pracy, wskazując na brak informacji zwrotnej, oceniającej pracownika po wykonaniu zadania czy polecenia. W zarządzaniu przez cele fundamentalne jest dokonywanie okresowych przeglądów postępu podejmowanych działań i ocena pracowników. W trakcie takiej analizy wspólnie można zdiagnozować pojawiające się trudności, łatwiej zareagować w przypadku potrzeby dokonania zmian, np. rewizji celów. Pracownicy, którzy na czas otrzymują informacje zwrotne, stają się efektywniejsi.

Podobna potrzebę można zdiagnozować dzięki interpretacji odpowiedzi w odniesieniu do kryteriów awansowania. Zdecydowana większość pracowników Centrum Obsługi Przedsiębiorcy za najbardziej sprawiedliwe kryteria awansowania uważała bardzo dobra ocenę dotychczasowej pracy oraz posiadanie predyspozycji $i$ kompetencji na awansowane stanowiska. Uznając istotność przyznawania awansów jako niezwykle ważnego elementu w realizacji procesu rozwoju zawodowego każdego pracownika, przy jednoczesnym potwierdzeniu przez samych pracownikow, że praca w Centrum Obsługi Przedsiębiorcy stymuluje rozwój kwalifikacji, ewidentnie można zauważyć, jak istotną rolę odgrywa ocena kierownictwa związana z praca poszczególnych pracowników. Bieżące ocenianie nie może nastapić bez zaangażowania i uczestnictwa, czyli podstawowych elementów systemu zarządzania przez cele. Dyrekcja musi spotykać się ze swoimi pracownikami, aby najpierw ustalić cele, a następnie po to, aby ocenić postępy w ich realizacji. Bez uczestnictwa spada efektywność, pracownicy tracą poczucie istotności wykonywania zadań, często popadają w rutynę i pracę wykonują odtwórczo, w efekcie osoby zarządzające instytucją nie mają wystarczających i klarownych argumentów, aby przyznawać awanse zawodowe.

Z odpowiedzi respondentów wyraźnie wyłania się oczekiwanie oceny własnej pracy przez dyrekcję oraz - co za tym idzie - uzyskanie informacji zwrotnej. Skoro, według ankietowanych pracowników Centrum Obsługi Przedsiębiorcy, najważniejszym czynnikiem, który powinien decydować o wzroście wynagrodzenia, jest dobra ocena kompetencji i efektów pracy, to niemożliwe staje się jej dokonanie w sytuacji braku bieżącej oceny po wykonaniu konkretnego zadania czy polecenia, na co wskazywały uzyskane odpowiedzi pracowników. Co więcej, zgłaszali oni „postulat” stałego przeprowadzania takiej oceny.

Niezwykle znamienny jest zdiagnozowany brak informacji zwrotnej ze strony przełożonych, uzasadniający wysokość premii uznaniowej przyznawanej poszczególnym pracownikom. Jeśli właśnie w tej części systemu wynagradzania, w której określono największy zakres swobody do implementacji rozwiązań innowacyjnych, nie zastosuje się podstawowych elementów zarządzania przez cele, oczekiwana zmiana w zakresie zbudowania efektywnego systemu wynagradzania nie nastapi. 
Próbując odnieść wyniki uzyskane w badaniu do możliwości zaimplementowania metody zarządzania przez cele w instytucji publicznej, jaka jest Centrum Obsługi Przedsiębiorcy, i sprzężenia jej z systemem wynagradzania w celu wywołania odpowiednich postaw i działań pracowników, które będą skutkować większą innowacyjnością organizacji, można wskazać katalog i sekwencję zagadnień, wokół których powinny ogniskować się działania kierownicze. Na początku należy jasno sprecyzować misję instytucji, a następnie określić strategię i wstępne cele do osiagnięcia w dłuższym okresie. Kolejnym krokiem będzie zaangażowanie kierowników niższego szczebla do opracowania celów cząstkowych, przypadających na poszczególne komórki organizacyjne, a biorąc pod uwage całą hierarchię organizacyjną - na każdego pracownika. W tym kontekście nieunikniony staje się proces omówienia, analizy, a często przewartościowania postawionych celów z pracownikami. Każdy członek zespołu powinien znać zakres własnego wpływu na cele całej jednostki. Im większe zrozumienie, tym większa odpowiedzialność, a w rezultacie skuteczność w osiagnięciu założeń przyjętych do realizacji. Trzeba również wyznaczyć zakres swobody, bowiem „ręczne sterowanie” przez kierownictwo poszczególnymi czynnościami stanowi zaprzeczenie metody zarządzania przez cele. Oczywiście, ostatniego fundamentalnego elementu, jakim jest dokonanie pomiarów postępu realizacji celów, oceny efektywności zastosowanych rozwiązań organizacyjnych itp., nie należy utożsamiać $\mathrm{z}$ ingerencją $\mathrm{w}$ samodzielność podczas wykonywania określonych planów. Wyraźnie oczekiwana przez pracowników sugestią jest dokonywanie oceny efektywności ich pracy na bieżąco, która będzie prowadzić do uzyskiwania obiektywnych informacji o jakości pracy, a to jest podstawowym warunkiem do zbudowania jasnych i zrozumiałych zasad wynagradzania pracowników, zwłaszcza w najbardziej skutecznej części, jaką może stać się dobrze zaprojektowany system premiowania i nagradzania.

\section{Literatura}

Cieślak R. 2008 Pomoc unijna dla przedsiebiorców, [w:] Fundusze Unijne 2007-2013: poradnik przedsiebiorcy, R. Cieślak (red.), Oficyna Wydawnicza „Unimex”, Wrocław.

Czapla T., Malarski M. 2001 Zarzadzanie personelem w matych i średnich przedsiębiorstwach wobec wyzwan XXI wieku, [w:] Polska w Europie 2000. Polskie nanki o zarzadzaniu wobec wyzwan XXI wieku, L. Pasieczny (red.), Warszawa.

Czapla T., Świątek-Barylska I. 2011 Znaczenie innowacyjności w śnietle badań wartości i systemón kompetencyjnych onganizacij, „Współczesne Zarządzanie”, nr 3.

Drucker P. F. 1994 Praktyka zarzqadzania, Akademia Ekonomiczna w Krakowie, Kraków.

Gadomska-Lila K. 2011 Budowanie kultury innowacyjności w swietle badań empirycznych, „,Współczesne Zarządzanie", nr 1.

Krukowski K. 2011 Zarz̨adzanie procesowe w administracji publičnej, „Współczesne Zarządzanie", nr 1.

Narodowe Strategiczne Ramy Odniesienia 2007-2013 wspierajace w:rost gospodarçy $i$ zatrudnienie 2006, Ministerstwo Rozwoju Regionalnego, Warszawa.

Penc J. 2010 Humanistyczne wartości zarzadzania w poszukiwaniu sensu menedżerskich dziatań, Difin, Warszawa. 
Regulamin wynagradzania pracowników Centrum Obstugi Przedsiębiory prayjety na podstawie Zarzqdzenia Nr 1/10 Dyrektora Centrum Obstugi Przedsiebiory z dnia 5 stycznia 2010 roku.

Roodenburg-Jager H. A., Klijn L. P. M., Jangsma-Lievaart M. R. 1993 Powiqzania mięzy charakterem efektów a wynagrodzeniami i kultura organizacyjna, [w:] Innowacyjne strategie plac, S. Borkowska, B. Urbaniak (red.), Przedsiębiorstwo Specjalistyczne „Absolwent", Łódź-Warszawa.

Rozporzqdzenie Rady Ministrów z dnia 18 marca 2009 roku w sprawie uynagradzania pracowników samorzqdowych, Dz.U. z 2009 r., Nr 50, poz. 398.

Stawasz E. 1999 Innowacje a mała firma, Wydawnictwo Uniwersytetu Lódzkiego, Łódź.

Stoner J. A. F., Freeman R. E., Gilbert D. R. Jr. 2001 Kierowanie, wydanie II, Wydawnictwo PWE, Warszawa.

Styś A. 2011 Innowacyjność - postrzeganie, znaczenie, unarunkowania - opcja marketingowa, „Współczesne Zarządzanie”, nr 4.

Ustawa z. dnia 26 czerwca 1974 roku. Kodeks pracy (tekst jedn.: Dz. U. z 1998 roku, Nr 21, poz. 94 z późn. zm.).

Ustawa z. dnia 12 grudnia 1997 roku o dodatkowym wynagrodzeniu rocznym pracowników jednostek sfery budżetowej (Dz. U. z 1997 roku, Nr 160, poz. 1080 z późn. zm.).

Ustawa z. dnia 6 grudnia 2006 roku o zasadach prowadzenia polityki rozwoju (Dz. U. z 2009 roku, $\mathrm{Nr} 84$, poz. 712 z późn. zm.).

Ustawa z dnia 21 listopada 2008 roku o pracownikach samorzqdowych (Dz. U. z 2008 roku, Nr 223, poz. 1458).

Wiatrak A. P. 2011 Innovative Management in Public Organizations, „Współczesne Zarzadzanie", nr 1. 